\title{
Localization of molecular correlates of memory consolidation to buccal ganglia mechanoafferent neurons after learning that food is inedible in Aplysia
}

\author{
David Levitan, Ravit Saada-Madar, Anastasiya Teplinsky, and Abraham J. Susswein ${ }^{1}$ \\ The Mina and Everard Goodman Faculty of Life Sciences and The Leslie and Susan Gonda (Goldschmied) Multidisciplinary Brain \\ Research Center, Bar Ilan University, Ramat Gan 52900, Israel
}

\begin{abstract}
Training paradigms affecting Aplysia withdrawal reflexes cause changes in gene expression leading to long-term memory formation in primary mechanoafferents that initiate withdrawal. Similar mechanoafferents are also found in the buccal ganglia that control feeding behavior, raising the possibility that these mechanoafferents are a locus of memory formation after a training paradigm affecting feeding. Buccal ganglia mechanoafferent neurons expressed increases in mRNA expression for the transcription factor $A p C / E B P$, and for the growth factor sensorin-A, within the first $2 \mathrm{~h}$ after training with an inedible food. No increases in expression were detected in the rest of the buccal ganglia. Increased $A p C / E B P$ expression was not elicited by food and feeding responses not causing long-term memory. Increased $A D C / E B P$ expression was directly related to a measure of the efficacy of training in causing long-term memory, suggesting that $A p C / E B P$ expression is necessary for the expression of aspects of long-term memory. In behaving animals, memory is expressed as a decrease in the likelihood to respond to food, and a decrease in the amplitude of protraction, the first phase of consummatory feeding behaviors. To determine how changes in the properties of mechanoafferents could cause learned changes in feeding behavior, synaptic contacts were mapped from the mechanoafferents to the B31/B32 neurons, which have a key role in initiating consummatory behaviors and also control protractions. Many mechanoafferents monosynaptically and polysynaptically connect with B31/B32. Monosynaptic connections were complex combinations of fast and slow excitation and/or inhibition. Changes in the response of B31/B32 to stimuli sensed by the mechanoafferent could underlie aspects of long-term memory expression.
\end{abstract}

[Supplemental material is available for this article.]

In a number of learning paradigms affecting Aplysia withdrawal reflexes, the connection from mechanoafferent neurons to effectors has been a major focus of research on how neural plasticity is translated into behavioral change (Byrne and Kandel 1996; Liu et al. 1997; Kandel 2001; Roberts and Glanzman 2003; Sharma and Carew 2004; Hu et al. 2006; Reissner et al. 2006; Glanzman 2010). However, in learning paradigms affecting feeding in Aplysia and related animals, other neural sites have been implicated as sites of plasticity. For example, in one learning paradigm memory is expressed by changes in the properties of a neuron that biases the motor output toward ingestion in place of rejection (Nargeot et al. 1999). In another paradigm memory is expressed by the synchronization of interneurons driving a key neuron initiating ingestion (Nargeot et al. 2009). In a Lymnaea learning paradigm a neuron that excites feeding is tonically depolarized after training (Nikitin et al.2008). In these and in other learning paradigms affecting feeding (e.g., Baxter and Byrne 2006), the possible role of mechanoafferents in the formation and expression of long-term memory was not explored, probably because it is not immediately clear how mechanoafferents might effect a learned change in feeding behavior. Thus, the role of mechanoafferents and their connections in longterm memory formation seems restricted to withdrawal reflexes.

This report examines the role of mechanoafferents in memory formation following an associative learning task affecting Aplysia feeding, learning that food is inedible. In this task Aplysia attempt

'Corresponding author

E-mail abrham.susswein@biu.ac.il

Article is online at http://www.learnmem.org/cgi/doi/10.1101/lm.026393.112. to swallow a tasty but tough food that is impossible to swallow. Attempts to swallow repeatedly fail, and the animals learn to stop responding (Susswein et al. 1986; Schwarz et al 1988, 1991; Botzer et al. 1998; Katzoff et al. 2002, 2006, 2010; Cohen-Armon et al. 2004; Levitan et al. 2010; Michel et al. 2010, 2011). Previous studies (Levitan et al. 2008; Michel et al. 2011, 2012) used molecular markers of memory to localize the learning to specific ganglia. After training with inedible food, the markers were found in the buccal, but not in the cerebral, pleural, or pedal ganglia of Aplysia (Levitan et al. 2008; Michel et al. 2011). The buccal ganglia contain a central pattern generator (CPG) organizing repetitive consummatory feeding behaviors, as well as motor neurons innervating buccal muscles (Elliott and Susswein 2002), which move the toothed radula (Ye et al. 2006; Neustadter et al. 2007). The ganglia also contain primary mechanoafferents innervating the interior of the mouth (Evans and Cropper 1998; Walters et al. 2004). Some of these mechanoafferents have properties similar to the mechanoafferents in abdominal and pleural ganglia that initiate withdrawal reflexes and that are a locus of long-term memory formation. We used expression of molecular markers to determine whether these mechanoafferents may be a site of plasticity underlying changes in behavior following training with inedible food.

One of the molecular markers used in previous studies was the transcription factor $A p \mathrm{C} / \mathrm{EBP}$, the Aplysia homolog of a transcription factor that is a marker of processes leading to longterm memory in other learning tasks (Alberini 2009). ApC/EBP synthesis is necessary for long-term facilitation of mechanoafferent-to-motor-neuron synapses in Aplysia (Alberini et al. 1994), a correlate of long-term sensitization (Cleary et al. 1998). In 
mammals, increased expression of a specific isoform $(C / E B P \beta)$ in the hippocampus is necessary for long-term memory after inhibitory avoidance training (Taubenfeld et al. 2001a,b), and C/ EBP $\beta$ expression in the amygdala is necessary for reconsolidation (Milekic et al. 2007). The present report used expression of ApC/ EBP to determine whether buccal ganglia mechanoafferents are a site at which memory is formed.

We have also examined possible changes in sensorin-A, a molecular marker of long-term memory formation in mechanoafferents mediating withdrawal. Sensorin-A is a peptide growth factor that is expressed exclusively in mechanoafferent neurons (Brunet et al. 1991), including in some of the buccal ganglia mechanoafferents (Walters et al. 2004). In other systems (Hu et al. 2004, 2006; Cai et al. 2008), treatments causing long-term facilitation of mechanoafferent-to-motor-neuron synapses require increased expression of sensorin-A, which is released by the mechanoafferents and is sensed by them by binding to autocrine receptors. Sensorin-A in turn causes activation of mitogen-activated protein kinase (MAPK), as well as the growth of new synaptic varicosities, thereby strengthening connections between the mechanoafferents and motor neurons. MAPK is also an intermediate in learning that food is inedible (Michel et al. 2011), and the role of increased sensorin expression in the buccal ganglia mechanoafferents could be similar to that in the mechanoafferents responsible for longterm sensitization.

We found that buccal ganglia mechanoafferents with properties similar to those initiating withdrawal display an increase in ApC/EBP transcription after training with inedible food. The transcription of sensorin-A was also increased after training. The buccal ganglia mechanoafferents were found to produce monosynaptic and polysynaptic fast and slow postsynaptic potentials onto key neurons initiating and shaping Aplysia consummatory feeding behaviors, potentially allowing them to cause behavioral changes after training. The findings suggest that molecular mechanisms present in a specific cell type (i.e., mechanoafferents) may be used to produce learning affecting very different behaviors.

\section{Results}

\section{Buccal ganglia mechanoafferents affect a key CPG neuron} The s1 and s2 buccal ganglia mechanoafferent neurons (Fig. 1) have many features of morphology, physiology, and pharmacology in common with mechanoafferent neurons in the cerebral, pleural, and abdominal ganglia of Aplysia (Walters et al. 2004). Pleural and abdominal ganglia mechanoafferent respond to stimulation

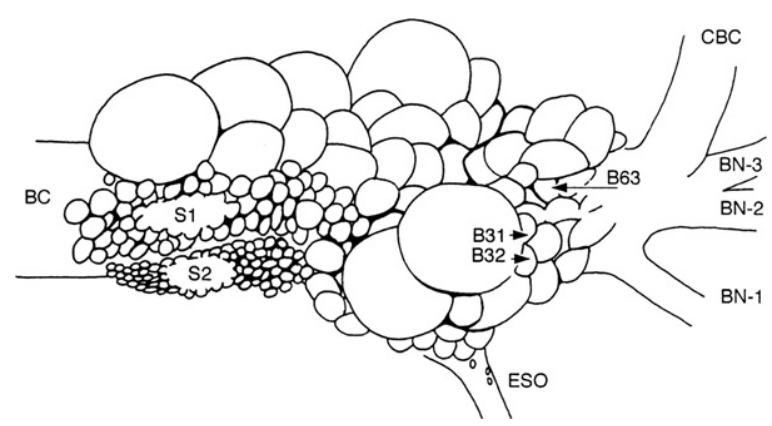

Figure 1. One of the two bilaterally symmetrical buccal ganglia. The location of the $s 1$ and s2 mechanoafferent neuron clusters is shown. These were separated from the rest of the ganglia. Also shown are the locations of neurons B31/B32 and B63, which are discussed below. (BN-1, BN-2, $\mathrm{BN}-3$ ) Buccal nerves 1-3; (CBC) cerebro-buccal connective; $(\mathrm{BC})$ buccal commisure, which connects the two buccal ganglia; (ESO) esophageal nerve. of the skin, and connect to motor neurons and interneurons controlling withdrawal. The mechanoafferents and their connections to motor neurons have been extensively studied as focal points of both associative and nonassociative learning affecting withdrawal reflexes (Byrne and Kandel 1996; Kandel 2001; Hu et al. 2006; Reissner et al. 2006; Glanzman 2010). Since withdrawal reflexes are initiated by activation of the mechanoafferents, changes in the connectivity between mechanoafferents and their followers can easily explain changes in withdrawal behaviors resulting from learning.

In learning that food is inedible, animals attempt to swallow a tough food. As animals learn, there is a reduction in attempts to swallow food, followed by a cessation of feeding (Susswein et al. 1986; Schwarz et al. 1988). The buccal ganglia s1 and s2 mechanoafferents respond to stimuli within and about the mouth (Walters et al. 2004) and could be activated by attempts to swallow, stimuli that have an essential role in creating learned changes of feeding behavior (Schwarz et al. 1988). However, because relatively little is known about the connectivity of the mechanoafferents to neurons organizing feeding behavior, it would not be possible to predict how changes in the properties of the mechanoafferents would give rise to learned changes in feeding behavior. Thus, before examining whether the buccal ganglia mechanoafferents are affected by learning that food is inedible, it was first important to examine the possible connectivity of the buccal ganglia mechanoafferents to key identified neurons that organize feeding.

Previous studies showed that the s1 and s2 mechanoafferents synaptically excite a number of different populations of buccal ganglia neurons (Fiore and Meunier 1979), but their connections to key CPG neurons initiating feeding has not been explored. To examine whether changes in the mechanoafferent neurons could affect the initiation of feeding, we examined whether the mechanoafferent neurons affect B31/B32. These two neurons have a key role in deciding to initiate a consummatory feeding response (Hurwitz et al. 2008; Saada et al. 2009). In addition, the B31/B32 neurons innervate the I2 muscle (Hurwitz et al. 1994, 2000), whose activity causes radula protraction (Hurwitz et al. 1996). Rejection of food, which becomes more common after training (Susswein et al. 1986), is characterized by a longer and more powerful protraction than is swallowing (Ye et al. 2006; Neustadter et al. 2007).

Experiments were on five buccal ganglia that were removed from animals and then treated with a high divalent cation solution (HiDi), which raises thresholds and thereby blocks polysynaptic chemical connections. In each preparation, the possible monosynaptic connections from $10 \mathrm{~s} 1$ and from 10 s2 neurons to a B31/B32 neuron (see Fig. 1) were determined.

Both the s1 and s2 populations contained neurons that connected to the B31/B32 neurons in HiDi (Fig. 2A). In neither population were all of the sampled cells connected to B31/B32. For the 1 cluster, an average of $6.8( \pm 1.6 \mathrm{SD})$ of the 10 neurons tested had monosynaptic connections to the B31/B32 neurons. For the s2 cluster, an average of $2.2( \pm 1.8 \mathrm{SD})$ of the 10 neurons tested had monosynaptic connections to the B31/B32 neurons. Presumed monosynaptic connections in HiDi were often complex, with many cells showing both fast and slow components (Fig. 3A). Some neurons displayed only fast or slow postsynaptic potentials (PSPs). Slow PSPs were somewhat more common (59.5\% of all PSPs) than were fast PSPs ( $40.5 \%$ of all PSPs). Both excitatory and inhibitory fast and slow PSPs were present, with excitation (87.6\% of all PSPs) much more common than inhibition (12.4\% of all PSPs). All but two of the fast excitatory postsynaptic potentials (EPSPs) (27 of 29 EPSPs) displayed prominent depression on repetition of mechanoafferent cell spikes (Fig. 3A3), with one example of a fast EPSP showing facilitation (not shown), and another showing little change (Fig. 3A1). Although PSPs from 
A Connected to B31/B32

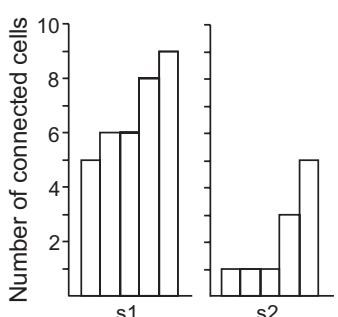

B B) Type of connection

1) fast EPSP 2) slow EPSP 3) fast IPSP 4) slow IPSP

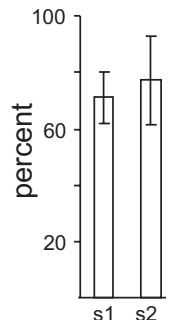

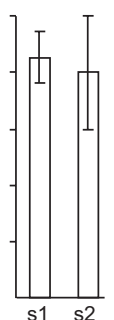
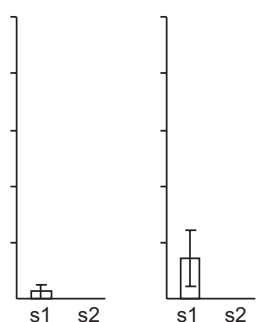

Figure 2. Monosynaptic connectivity of $s 1$ and $s 2$ neurons with $B 31 / B 32$. (A) Of the $10 s 1$ and $s 2$ neurons sampled in each of the five preparations, the number of neurons displaying monosynaptic connections to B31/B32 is shown. Significantly more s1 than s2 neurons monosynaptically affected B31/ B32 $\left(P=0.03 ; t_{(4)}=3.20\right)$. The connections displayed both fast and slow and both excitatory and inhibitory components. (B) We examined possible differences in the patterns of connectivity between $\mathrm{s} 1$ and $s 2$ cells by testing whether there were differences in the likelihood for observing fast or slow, or excitatory or inhibitory connections, between the $s 1$ and $s 2$ clusters (1-4). The percent of all observed synapses that were fast, slow, excitatory, or inhibitory was calculated for each preparation for the $s 1$ and for the $s 2$ neurons. No significant differences were found between the $s 1$ and $s 2$ neurons (for fast EPSPs: $P=0.8, t_{(4)}=0.27$; for slow EPSPs: $P=0.8, t_{(4)}=0.21$; for fast IPSPs: $P=0.38, t_{(4)}=1.0$; for slow IPSPs: $P=0.22, t_{(4)}=1.46$; all tests are paired two-tailed $t$-tests). Means and standard errors are shown.

the s1 neurons were more common than were PSPs from the s2 neurons, there were no significant differences in the distribution of the different types of PSPs between the s1 and s2 neurons (Fig. 2B).

High divalent cation solutions minimize the effects of a polysynaptic connection by raising neuron thresholds, thereby making it unlikely that interneurons will fire in response to synaptic excitation and release transmitter. However, neurons that are electrically coupled to either the presynaptic or postsynaptic neuron may fire, since they are not depolarized by transmitter release. B31/B32 are electrically coupled to B63, which in turn excites B31/B32 via fast (Hurwitz et al. 1997) and slow EPSPs (Saada et al. 2009). In addition to being electrically coupled to B31/B32, B63 also has a lower firing threshold than does the B31/B32 axon (Susswein et al. 2002; Saada et al. 2009). Recordings from B31/ B32 after firing buccal ganglia mechanoafferents showed fast EPSPs from B63 (Fig. 3A1), in addition to direct EPSPs from the mechanoafferent cell. Since B63 elicits both fast and slow excitation of B31/B32 (Dembrow et al. 2004; Saada et al. 2009), firing of B63 in response to mechanoafferent firing raises the possibility that some of the slow EPSPs elicited by the mechanoafferents may have been via B63 activity. However, this possibility is unlikely, since the slow EPSPs from mechanoafferents to B31/B32 were usually seen in the absence of fast B63 EPSPs, which occur every time that B63 fires, and B63 firing was present only after strong depolarization of B31/B32 that resulted from a slow EPSP (see Fig. 3A1). In addition, the slow EPSPs that result from B63 firing are generally elicited at high B63 firing frequencies (Saada et al. 2009), which were never seen.

The connections from buccal ganglia mechanoafferents to B31/B32 were also examined in artificial seawater (ASW), in which polysynaptic connections are not blocked (Fig. 3B). Firing of mechanoafferents elicited heterogeneous responses of variable length, which combined fast and slow responses. In some cases (e.g., Fig. 3B1) polysynaptic EPSPs were seen even in neurons that did not display a monosynaptic connection. In other cases (e.g., Fig. 3B2) the mechanoafferents elicited a complete buccal motor program that was expressed as a slow, ramp depolarization of B31/B32, followed by a plateau B31/B32 depolarization that corresponds to radula protraction, and then repolarization that corre- sponds to radula retraction. Such motor programs are correlates of consummatory feeding behaviors in intact, behaving animals (Hurwitz et al. 1996). Thus, firing in buccal ganglia mechanoafferents is capable of inducing feeding behaviors. Modulation of the properties of the mechanoafferent neurons could readily account for aspects of the changes in feeding behaviors that are expressed by learning and memory after training with inedible foods.

\section{$A p C / E B P$ expression is present in mechanoafferent neurons}

We have reported that, after training with inedible food, $A p \mathrm{C} / \mathrm{EBP}$ is transcribed and translated in the buccal ganglia (Levitan et al. 2008). A subsequent study also localized the expression of MAP kinase after training to the buccal ganglia (Michel et al. 2011). In which buccal ganglia neurons does the expression of $A p C / E B P$ increase after training causing long-term memory? As was done in other gene expression experiments in Aplysia (Kuhl et al. 1992; Liu et al. 1997), we separated mechanically the buccal ganglia into two compartments. One compartment contained the $\mathrm{s} 1$ and s 2 primary mechanoafferent neurons, and the other contained the rest of the neurons in the ganglia. To be certain that the mechanoafferent clusters were separated from the rest of the neurons, we used sensorin-A mRNA as a positive marker for mechanoafferent cell clusters, since sensorin-A is enriched in these mechanoafferent neurons (Walters et al. 2004). Sensorin-A mRNA levels in the combined s1 and s2 mechanoafferent neuron cluster were 8.5 times higher than in the rest of the ganglia (difference between sensorin-A mRNA expression in the two compartments: $P=0.02$, $U_{(4,9)}=2$; two-tailed Mann-Whitney $U$-test), indicating that the dissection successfully separated the mechanoafferent cells from the rest of the buccal ganglia.

As in previous experiments measuring $A p C / E B P$ after training with inedible food (Levitan et al. 2008), ApC/EBP mRNA levels in the two buccal ganglia compartments were measured $15 \mathrm{~min}$ and $2 \mathrm{~h}$ after training. The expression of $A p C / E B P$ was normalized to that of histone $\mathrm{H} 4$, which is not expected to change as a result of training (Guan et al. 2002). In addition, a direct test of H4 expression in the buccal ganglia of naive $(N=4)$ and of trained $(N=6)$ animals showed no significant change in $\mathrm{H} 4$ expression $\left(P=0.89, t_{(8)}=0.14\right)$. As controls, ApC/EBP mRNA levels were also measured in ganglia dissected from naive, untrained animals, as well as in ganglia dissected after stimulating the lips with netted food, but not allowing the food to enter the mouth. This procedure does not cause long-term memory (Schwarz et al. 1988; Katzoff et al. 2006, 2010) or induce molecular correlates of memory formation (Cohen-Armon et al. 2004; Levitan et al. 2008), but does elicit feeding responses, thereby controlling for the possibility that $A p C / E B P$ is elicited by exposure to food and feeding responses per se, rather than being elicited by training.

In the sensory neuron compartment, there were significant increases in ApC/EBP mRNA levels both 15 min (Fig. 4A1) and $2 \mathrm{~h}$ (Fig. 4A2) after lip stimulation alone. However, training with inedible food caused large additional increases in ApC/EBP levels over those in lip-stimulated controls, both $15 \mathrm{~min}$ and $2 \mathrm{~h}$ after the treatments. These data indicate that training leading to longterm memory caused an increase in $A p C / E B P$ expression in the 
A

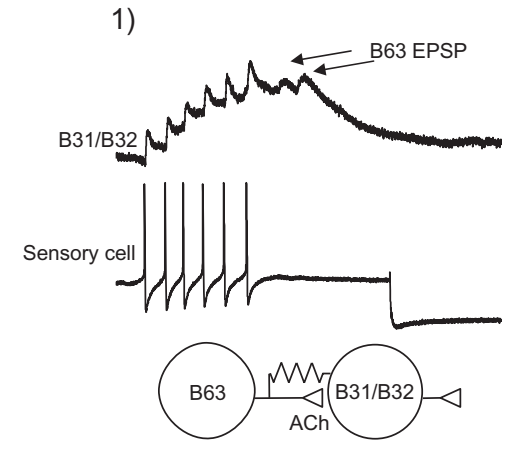

2)

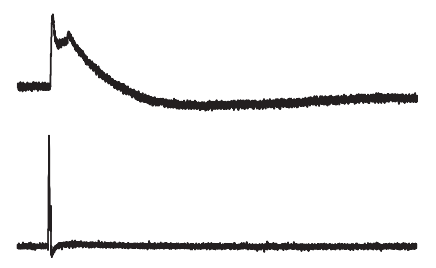

3)
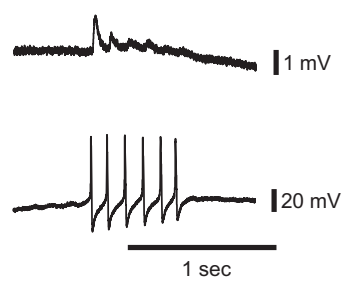

B

1)

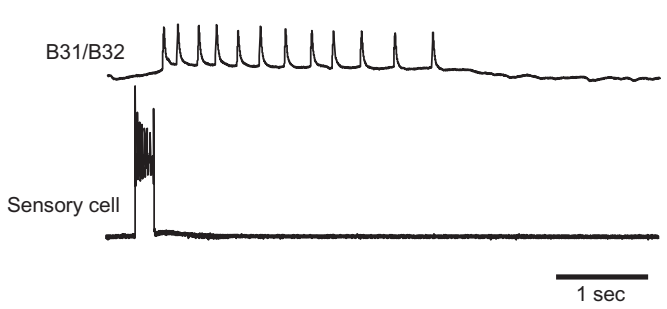

2) $15 \mathrm{mV}$ $20 \mathrm{mV}$

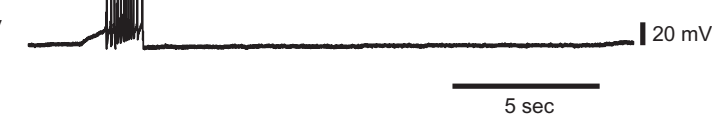

Figure 3. Examples of synaptic connections from buccal ganglia mechanoafferent neurons to $\mathrm{B} 31 / \mathrm{B} 32$. ( $A$ ) Monosynaptic connection recorded in a HiDi solution. (1) Firing a mechanoafferent neuron produces both fast and slow EPSPs in B31/B32. Note that two EPSPs from B63 are also elicited. B63 is electrically coupled to B31/B32, and it has a lower firing threshold than B31/B32. The depolarization of B31/B32 also depolarized the coupled B63 neuron, causing it to fire, eliciting the fast EPSPs. (2) A single spike in a mechanoafferent neuron caused a fast EPSP followed by a slow EPSP and a slow IPSP. (3) A number of mechanoafferent neuron spikes cause a series of fast EPSPs displaying strong depression, followed by a slow IPSP. (B) Examples of complex polysynaptic connections recorded in ASW. (1) Although a train of spikes in a mechanoafferent neuron produced no direct effect in B31/B32, the train was followed by a series of large EPSPs elicited by the firing of an unidentified neuron. (2) A train of spikes in a mechanoafferent neuron elicited a buccal motor program, after a delay.

sensory cells within 15 min after the training, and ApC/EBP levels remain elevated for at least $2 \mathrm{~h}$ after training. Although some of this increase can be attributed to lip stimulation and feeding per se, training causing long-term memory caused a large increase over that caused by lip stimulation.

Is the increased $A p C / E B P$ expression after training restricted to the sensory neurons, or are there also increases in $A p C / E B P$ expression in the rest of the ganglia? ApC/EBP mRNA levels were also measured in the nonsensory compartment $15 \mathrm{~min}$ and $2 \mathrm{~h}$ after training and compared with $A p C / E B P$ mRNA expression in naive animals and in animals in which the lips were stimulated without allowing the food to enter the mouth. There were no significant differences between naive and lip-stimulated controls, or between trained and lip-stimulated animals, at $15 \mathrm{~min}$ or $2 \mathrm{~h}$ after training. However, there was a significant increase between naive animals and trained animals 15 min after training, indicating that there may be a transient increase in $A p C / E B P$ expression at this time. Because the number of preparations in which the nonsensory compartment was examined $2 \mathrm{~h}$ after training was smaller than that for the sensory compartment, we cannot eliminate the possibility of a small increase in expression of $A p C / E B P$ that might have been detectable with more samples. However, at 15 min after training, comparable numbers of sensory and nonsensory compartments were examined.

These findings suggest that the increases in $A p C / E B P$ mRNA and protein after training that were found in previous work (Levitan et al. 2008) both $15 \mathrm{~min}$ and $2 \mathrm{~h}$ after training were largely due to changes in mRNA expression in the mechanoafferent cells. An additional test was performed to examine this hypothesis. ApC/EBP mRNA expression in the mechanoafferent cells was compared with that in the rest of the buccal ganglia in naive animals, as well as in ganglia removed $15 \mathrm{~min}$ after training. In naive animals, there was no significant difference in $A p C$ /EBP mRNA expression in the buccal mechanoafferents and the rest of the ganglia (Fig. 5A). In contrast, in trained animals the expression of $A p C / E B P$ was significantly increased in the mechanoafferent cell cluster, with respect to expression in the rest of the ganglion (Fig. 5B). Thus, even if the tendency for an increase in $A p C / E B P$ expression in the rest of the ganglion were significantly greater than in controls, had we examined more samples, the increase in the mechanoafferents would still be considerably larger.

\section{$A p C / E B P$ expression is correlated with aspects of memory formation}

Although $A p C / E B P$ expression in the mechanoafferent cells is increased by an experience leading to long-term memory over that caused by exposure to food and performance of feeding behavior, the increased $A p C / E B P$ could be caused by aspects of the training experience that do not directly lead to memory. If $A p C / E B P$ expression is related to subsequent memory formation, factors that influence $A p C / E B P$ expression may also influence memory. We tested the possible relationship between $A p C / E B P$ expression and aspects of memory formation, by examining whether training that leads to an increased expression of $A p C / E B P$ also leads to a greater expression of some measure of memory.

In previous studies, it was shown that entry of food into the mouth and attempts to swallow elicited by food in the mouth are critically required for the subsequent expression of memory (Schwarz et al. 1988; Cohen-Armon et al. 2004; Katzoff et al. 
A Mechanoafferents

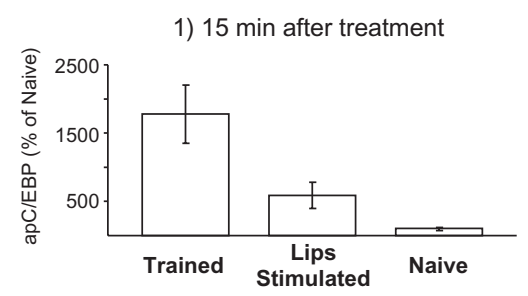

B Rest of Buccal Ganglia

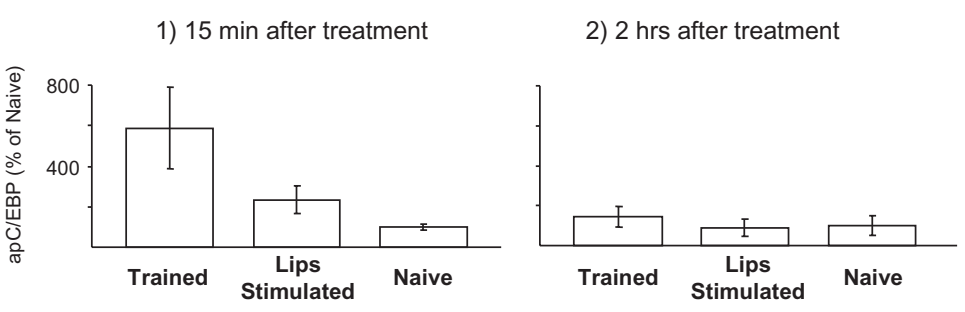

Figure 4. $A p C / E B P$ mRNA is increased in the sensory cells of the buccal ganglia after training, but not in the rest of the ganglia. ApC/EBP mRNA was normalized to ApH4 mRNA levels. Both transcripts were measured in the buccal sensory cells using quantitative RT-PCR. The value obtained from each animal in the trained, lip-stimulated, and naive groups was expressed as a percentage of the mean value of the naive group, which was set to $100 \%$. The graphs show the means and standard errors for each treatment. (A) Changes in $A p C / E B P$ mRNA expression in the sensory neuron clusters. (1) A comparison between $A p C$ /EBP levels in animals 15 min after treatment with lip stimulation $(N=4)$, with respect to that in naive animals $(N=4)$, revealed a significant increase caused by the lip stimulation $(U=0$, $P=0.028)$. Training $(N=5)$ caused a significant increase over that caused by the lip stimulation $(U$ $=1, P=0.032)$. (2) Two hours after treatment with lip stimulation $(N=8)$, there was still a significant increase in $A p C$ /EBP levels $(U=13, P=0.05)$, with respect to those in naive animals $(N=8)$. The $A p C$ EBP levels $2 \mathrm{~h}$ after training $(N=9)$ were also significantly increased over those caused by lip stimulation $(U=7, P=0.002)$. (B) Changes in C/EBP mRNA expression in the rest of the buccal ganglion. (1) A comparison between $A p C / E B P$ levels in animals 15 min after treatment with lip stimulation $(N=4)$, with respect to that in naive animals $(N=4)$, revealed no significant increase caused by the lip stimulation $(U=3, P=0.20)$. Training $(N=5)$ caused no significant increase over the level of $A p C / E B P$ in animals treated with lip stimulation $(U=6, P=0.412)$. However, a comparison of naive animals and trained animals showed a significant increase in trained animals, with respect to naives $(U=0 ; P=$ $0.016)$. (2) A comparison between $A p C / E B P$ levels in animals $2 \mathrm{~h}$ after treatment with lip stimulation $(N=4)$, with respect to that in naive animals $(N=4)$, revealed no significant increase caused by the lip stimulation $(U=9, P>0.5)$. Training $(N=5)$ caused no significant increase over the level of $A p C / E B P$ in animals treated with lip stimulation $(U=5, P=0.14)$. All $P$-values are from two-tailed Mann-Whitney U-tests.

2006). There is a strong correlation between the number of attempts to swallow and the time that food is in the mouth eliciting such attempts (Susswein et al. 1986). We examined whether the magnitude of the increased $A p \mathrm{C} / \mathrm{EBP}$ and aspects of expression of memory are both related to the time that food is in the mouth during training. In this experiment, the measure of memory used was the decrease in the time that food was in the mouth eliciting failed attempts to swallow during a test of memory, with respect to the time in the mouth eliciting swallows during the training. In a population of 33 animals, this measure of memory was significantly correlated with the time that food spent in the mouth during the training session, as might be expected if attempts to swallow cause the memory (Fig. 6A). The expression of $A p C / E B P$ in animals displaying a 24 -h memory was not tested, since preliminary experiments indicated that there is no increase in $A p C / E B P$ $24 \mathrm{~h}$ after training. For this reason, we examined $A p C / E B P$ expression $2 \mathrm{~h}$ after training in a separate experiment. The expression of $A p C / E B P 2 \mathrm{~h}$ after training was positively correlated with the time that food spent in the mouth during training (Fig. 6B). Thus, variations in the training leading to a greater expression of aspects of memory also lead to a larger expression of $A p C / E B P$. These data suggest that the increased $A p C / E B P$ expression may be directly re- lated to the formation of the memory. A previous study on long-term sensitization in Aplysia (Lyons et al. 2006) also found a positive correlation between $A p \mathrm{C} / \mathrm{EBP}$ expression and long-term memory.

\section{Sensorin-A expression is increased by training with inedible food}

Mechanoafferents similar to those in the buccal ganglia are a primary site of plasticity underlying long-term sensitization of withdrawal reflexes, and of their neural correlate facilitation of the mechanoafferent to motor synapse (Kandel 2001). Long-term facilitation is characterized by a number of molecular changes in the mechanoafferents. In addition to increased $A p C / E B P$ expression, the expression of sensorin-A mRNA and protein is increased. This increase is essential for the establishment of the long-term facilitation (Hu et al. 2006). Sensorin-A mRNA is also increased $2 \mathrm{~h}$ after 5 -HT treatment causing long-term facilitation (Sun et al. 2001; Hu et al. 2006) and declines to control levels at $24 \mathrm{~h}$ (Sun et al. 2001). Since the mechanoafferents of the buccal ganglia express sensorin-A (Walters et al. 2004), and these cells appear to be a locus of molecular changes underlying learning that food is inedible, we measured sensorin-A mRNA levels in the mechanoafferents of the buccal ganglia after training with inedible food. Sensorin-A mRNA levels were measured $15 \mathrm{~min}$ and $2 \mathrm{~h}$ after training. There was no significant difference in the sensorin-A mRNA levels 15 min after training, with respect to naive controls, which is consistent with previous findings on other mechanoafferent neurons exposed to serotonin (Hu et al. 2006). In contrast, there was a significant increase in sensorin-A mRNA $2 \mathrm{~h}$ after the training, with respect to naive controls (Fig. 7). However, the increase of sensorin-A mRNA in trained animals over that in naive controls was much smaller than was the increase in $A p C / E B P$ mRNA (twofold versus 10-fold). Values of sensorin-A mRNA for animals treated $2 \mathrm{~h}$ previously with lip stimulation were intermediate between those of naive controls and trained animals, and were not significantly different from values in naive animals or in trained animals (see Supplemental Fig. 1). Thus, we cannot eliminate the possibility that some or all of the increased expression of sensorin-A results from lip stimulation and its eliciting feeding behavior, rather than from the aspects of the training procedure that lead to memory.

\section{Discussion}

Experiences causing learning and memory initiate molecular processes in specific neurons, and thereby initiate changes in the properties of neurons and their interconnections. These changes are then expressed as a change in behavior. A first step in understanding how molecular processes cause behavioral change is to localize the molecular processes to specific neuron populations (Gusev et al. 2005; Hatakeyama et al. 2006; Kubik et al. 2007) or 
A

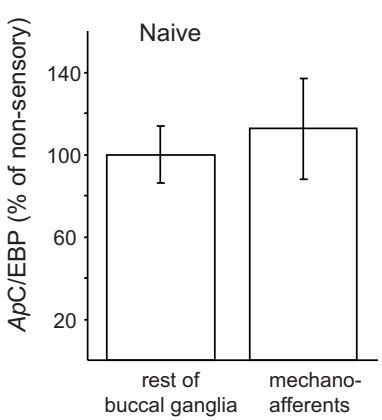

B

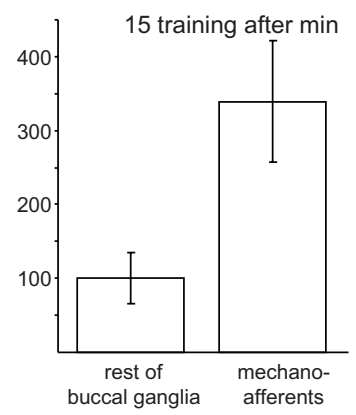

Figure 5. Comparison of $A p C / E B P$ expression in mechanoafferent versus non-mechanoafferent clusters of the buccal ganglia. For naive animals, expression in the mechanoafferents and in the rest of the ganglia for each animal was normalized to the mean expression in the non-mechanoafferent compartment of naive animals. Similarly, for trained animals, expression in the mechanoafferents and in the rest of the ganglia for each animal was normalized to the mean expression in the non-mechanoafferent compartment of trained animals. $(A)$ In naive animals $(N=4)$, there was no significant difference in expression of $A p C / E B P$ in the mechanoafferent versus the non-mechanoafferent compartments of the buccal ganglia $\left(P=0.63, t_{(3)}=0.54\right)$, whereas $(B)$ 15 min after training $(N=5)$ expression of $A p C / E B P$ in the mechanoafferents was significantly elevated over that in the rest of the buccal ganglia $(P=0.032, U(5,5)=2$; two-tailed Mann-Whitney $U$-test $)$.

brain regions (Frankland et al. 2004; Maviel et al. 2004; Kubik et al. 2007; Mamiya et al. 2009).

Molluscan feeding is a model system for determining cellular processes underlying learning and memory. Neuronal pathways generating, expressing, and modulating feeding have been mapped, and the properties of key neurons and their synaptic connections have been described (Benjamin et al. 2000; Elliott and Susswein 2002; Cropper et al. 2004). The behaviors produced by these circuits have also been examined (e.g., Chiel et al. 2009). We have used Aplysia feeding as a model system to localize molecular changes arising from training to specific neurons. Later studies will examine how the neurons expressing these changes cause behavioral changes.

After training with inedible food, $A p C / E B P$ is transcribed and translated in the buccal ganglia, but no changes were found in

other ganglia mediating aspects of feeding (Levitan et al. 2008). The buccal ganglia contain motor neurons that are effectors of feeding, a CPG organizing consummatory behaviors (Elliott and Susswein 2002; Cropper et al. 2004), and key interneurons that bias the system to choose among different consummatory behavior (Hurwitz et al. 1997; Nargeot et al. 1999; Jing and Weiss 2001, 2002). The ganglia also contain mechanoafferent neurons (Fiore and Meunier 1979) of relatively unknown function, which have properties similar to the well-studied mechanoafferent in the abdominal and pleural ganglia (Walters et al. 2004), and additional peptidergic sensory neurons that innervate the radula (Miller et al. 1994; Borovikov et al. 2000) and connective tissue attaching the buccal ganglia to the feeding apparatus (Evans and Cropper 1998; Evans et al. 1999).

We have localized molecular changes following training with inedible food to the s1 and s2 mechanoafferent neurons (Fig. 1). Training caused an increase in mRNA levels of $A p C / E B P$ (Fig. 4) and of sensorin-A (Fig. 7). In naive animals ApC/EBP is expressed equally in the mechanoafferent and non-mechanoafferent neurons, but after training expression is enriched in the mechanoafferent neurons (Fig. 5). The increased ApC/EBP expression is probably directly related to long-term memory formation, since lip stimulation eliciting feeding responses, but not memory, did not cause increased $A p C / E B P$. In addition, there are correlations between a measure of the efficacy of training, expressed by the time in the mouth during training, and ApC/EBP mRNA expression, and between the time in the mouth during training and a measure of long-term memory, expressed by a reduction of time in the mouth during a test of memory (Fig. 6). Sensorin-A is expressed exclusively in mechanoafferent neurons (Brunet et al. 1991), and expression of sensorin-A increases as a result of the training procedure (Fig. 7). However, although this finding is consistent with these neurons being a site of plasticity when Aplysia are trained with inedible foods, we were unable to determine whether the increased expression of sensorin- $\mathrm{A}$ is a specific result of aspects of the training that lead to memory formation.

Increases in both $A p C / E B P$ and sensorin-A expression in mechanoafferents are necessary for long-term memory following other training tasks affecting Aplysia behavior (Alberini et al. 1994; Hu et al. 2006). C/EBP is a transcription factor (Alberini 2009), and its production in the buccal ganglia mechanoafferents is likely to initiate the transduction of later genes that function in memory formation. Sensorin-A is a growth factor that is transported to synapses onto target neurons, where its activity is regulated
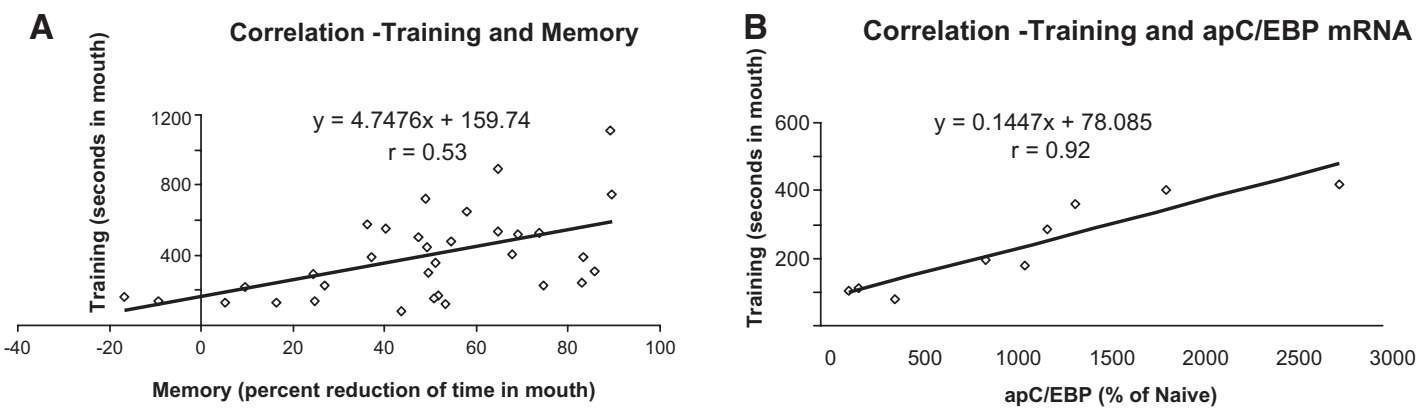

Figure 6. Positive correlations between training and memory $(A)$ and between training and $A p C / E B P$ mRNA expression (B). Efficacy of training was expressed as the time (in seconds) that food spent in the mouth eliciting attempts to swallow during the training. ApC/EBP mRNA was normalized to the $\mathrm{ApH} 4 \mathrm{mRNA}$ level. Both transcripts were measured in the buccal mechanoafferents using quantitative RT-PCR. The value of each trained animal was expressed as a percentage of mean value measured in naive animals, which was set to $100 \%$. $(A)$ A positive linear correlation was seen between the efficacy of training and memory, as measured by a percent decrease in the time that food was in the mouth during the test $24 \mathrm{~h}$ after the training. There was significant positive correlation between training intensity and 24 -h memory $\left(P=0.001 ; t_{(31)}=3.4 ; N=33\right.$; two tailed $t$-test). (B) A positive linear correlation was also seen between the efficacy of training and the expression of training-induced $A p C / E B P$ mRNA measured $2 \mathrm{~h}$ after the training in the buccal mechanoafferents $\left(P=0.0004, t_{(7)}=6.2 ; N=9\right.$; two tailed $t$-test). 
A

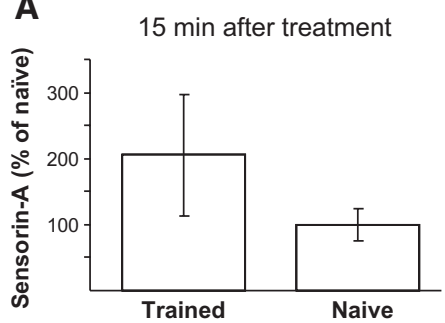

Figure 7. Sensorin-A mRNA is increased in the buccal mechanoafferents $2 \mathrm{~h}$ after training. The mRNA of sensorin-A was measured $15 \mathrm{~min}$ $(A)$ and $2 \mathrm{~h}(B)$ after training and compared with that in naive animals. Sensorin-A mRNA was normalized to $A p H 4$ mRNA levels. The value measured in each animal is expressed as a percentage of the mean value obtained in all naive animals, which was set to $100 \%$. The graph displays the means and standard errors. There was no significant difference $15 \mathrm{~min}$ after training $\left(P=0.35, t_{(7)}=0.99\right.$, two tailed $t$-test; trained animals $N=5, N=4$ naive animals). In contrast, there was a significant difference in sensorin-A mRNA $2 \mathrm{~h}$ after training $\left(P=0.049, t_{(15)}=2.13\right.$, two tailed t-test. $N=9$ trained animals, $N=8$ naive animals).

by experiences causing memory (Hu et al. 2004, 2010; Wang et al. 2009). In mechanoafferent-to-motor synapses that are affected by sensitization, autocrine sensorin effects regulate the activation of MAPK, which is necessary for subsequent long-term facilitation, as well as the growth of new synaptic varicosities (Hu et al. 2004). MAPK is also an intermediate in learning that food is inedible (Michel et al. 2011), and the role of increased sensorin expression in the buccal ganglia mechanoafferents could be similar to that in the mechanoafferents responsible for long-term sensitization.

Many aspects of behaviors are changed by the training, and it would therefore be surprising if molecular changes associated with memory formation were restricted to a small population of neurons such as the buccal ganglia mechanoafferents. Thus, after training animals are less likely to try to find food, or to attempt to bite it (Chiel and Susswein 1993). When they do bite the food, there are fewer attempts to swallow before the food leaves the mouth (Schwarz et al. 1988). Food-finding and ingestion are complex behaviors requiring the coordination of many neurons located in different ganglia, but the molecular changes that have been detected are restricted to the buccal ganglia mechanoafferents.

The seeming contradiction between the widespread changes in behavior and the narrow locus of expression of molecular correlates of learning found in this and in previous papers (Levitan et al. 2008; Michel et al. 2011) can be explained in a number of ways. First, changes in the expression of $A p C / E B P$ may not be restricted to the buccal ganglia mechanoafferents, as was shown in conditioned taste aversion in Lymnaea (Hatakeyama et al. 2006). When examining tissues such as the non-mechanoafferent components of the buccal ganglia or the cerebral ganglion, even large changes in a small number of cells may not be detected. Second, changes in the expression of molecules other than those investigated could also be initiated by training, and these could be expressed more widely in neurons other than the buccal ganglia mechanoafferents. This in consistent with an earlier finding that blocking polyADP-ribosylation, a process necessary for longterm memory after training with inedible food (Cohen-Armon et al. 2004), does not affect $A p C$ /EBP expression after training (Levitan et al. 2008). Third, later rounds of mRNA synthesis occurring after the periods examined may be expressed more widely in additional neurons. Fourth, the synaptic outputs of the mechanoafferent neurons may directly or indirectly affect many neurons with differing functions in regulating feeding.

How could the buccal ganglia mechanoafferents mediate behavioral changes during training with inedible food, or during a test of memory? The neurons are likely to be activated by the training, since they have receptive fields in the muscular buccal mass, in the buccal cavity and radula, in the esophagus, and in the perioral zone (Walters et al. 2004), all of which are stimulated by attempts to swallow inedible food during training. In addition, the mechanoafferents are depolarized by buccal motor programs even without sensory input (Susswein and Byrne 1988). The mechanoafferents also contain FRFamide and FMRFamide neuropeptides, which together bias buccal motor program toward egestion (Vilim et al. 2010), as is seen during training with inedible food (Schwarz et al. 1988). Moreover, the buccal ganglia mechanoafferents also express nitric oxide synthase (NOS), the enzyme responsible for NO production (see Supplemental Fig. 2). Memory formation is blocked by treating Aplysia with NOS blockers or with NO scavengers (Katzoff et al. 2002) during training, indicating the $\mathrm{NO}$ production during training is required for memory formation. NO signals difficulty in swallowing the food, and may bias the buccal ganglia toward rejection of food (Katzoff et al. 2006, 2010).

Changes in gene expression in the buccal ganglia mechanoafferents could cause changes in the properties of the mechanoafferents that are expressed as changes in behavior during tests of memory. First, the response properties of the mechanoafferents in response to food may change in a manner appropriate to a reduction in response to inedible food, thereby releasing more or less of a transmitter. Second, connections to postsynaptic follower of the mechanoafferents could be regulated, so as to produce a changed output, even if the response of the mechanoafferents to food is unaltered.

We have shown that many mechanoafferent neurons have monosynaptic and polysynaptic connections with the B31/32 neurons (Figs. 2, 3), which have a major role in deciding whether or not to initiate a consummatory feeding response (Hurwitz et al. 2008). As animals learn and remember, the likelihood to respond to food decreases (Schwarz et al. 1988). After they are depolarized, B31/B32 neurons fire at a steady rate (Hurwitz et al. 1996). Since B31/B32 are the major motor neuron innervating the I2 muscle, causing protraction (Hurwitz et al. 2000), the amplitude of protraction is specified largely by how long B31/B32 remain depolarized and fire. Protraction is weaker during swallowing than during other consummatory responses, such as biting or rejection (Ye et al. 2006; Neustadter et al. 2007). Training causes a decrease in swallows and an increase in rejection (Susswein et al. 1986). Changes in the amplitude of the connections from the mechanoafferents to B31/B32 could underlie some of the changes in behavior that characterize learning and memory that food is inedible. In addition, NO stabilizes the resting potential of the B31/32 cells, thereby making them less excitable (Miller et al. 2011). Changes in the release of NO by the $s 1$ and s2 mechanoafferent cells when they respond to food could be an additional mechanism by which these cells could produce changes in feeding behavior.

The mechanoafferents also produce fast and slow synaptic potentials onto other buccal ganglia neurons, including a fast EPSP onto B4/B5 (Fiore and Meunier 1979-they termed B4/B5 the A cells). B4/5 firing biases buccal motor programs toward rejection (Warman and Chiel 1995; Ye et al. 2006). Modulation of the mechanoafferent output onto B4/B5 as a result of training could also contribute to the choice between different consummatory behaviors after training.

In work on abdominal ganglia mechanoafferents eliciting withdrawal, in naive Aplysia $\sim 90 \%$ of the mechanoafferents synapse onto motor neurons. Training causing long-term habituation decreased the number of sensory to motor neuron connections, and subsequent training causing long-term sensitization restored the erased synapse (Castellucci et al. 1978; Carew et al. 1979). The finding that the number of s1 and s2 neurons 
connected to $\mathrm{B} 31 / \mathrm{B} 32$ varies considerably from animals to animals (Fig. 2A) suggests that the individual experiences of each animal prior to the experiment might have affected the likelihood of the connections.

Although previous papers (Levitan et al. 2008; Michel et al. 2011) identified the buccal ganglia as a site of plasticity for learning that food is inedible, the finding that mechanoafferents are a site of plasticity was unexpected, but was serendipitous. The buccal ganglia mechanoafferent neurons have many features of morphology, physiology, and pharmacology in common with other mechanoafferent neurons in the cerebral, pleural, and abdominal ganglia of Aplysia (Walters et al. 2004). The major difference between the buccal ganglia mechanoafferents and those in the other ganglia seems to be in their connectivity. The buccal ganglia mechanoafferents respond to stimuli within and about the mouth, and are connected to motor neurons and interneurons controlling feeding, whereas mechanoafferents in other ganglia respond to stimulation of the skin, and connect to motor neurons and interneurons controlling withdrawal. Mechanoafferent neurons in the pleural and abdominal ganglia, and their connections to motor neurons, have been extensively studied as focal points of both associative and nonassociative learning affecting withdrawal reflexes (Byrne and Kandel 1996; Kandel 2001; Hu et al. 2006; Reissner et al. 2006; Glanzman 2010). Localization of learning to the buccal ganglia mechanoafferents suggests that many of the well-documented molecular and physiological changes that contribute to learning and memory affecting withdrawal will also be relevant to learning that food is inedible. Future studies will be needed to confirm this possibility. Localizing learning to mechanoafferents suggests the interesting possibility that very different learning phenomena, such as learning that food is inedible and sensitization or classical conditioning of withdrawal reflexes, will share common cellular mechanisms. The major difference between these types of learning will be in the circuits in which the cellular mechanisms are embedded, which give rise to different behaviors.

\section{Materials and Methods}

\section{Animals}

Experiments were performed on Aplysia californica (50-150 g) purchased from Marinus Scientific (Garden Grove, CA) or Santa Barbara Marine Bio (Santa Barbara, CA). As described for previous experiments (Botzer et al. 1998; Katzoff et al. 2002, 2006), five to six animals were maintained in a cage immersed in 900-L tanks of aerated, filtered Mediterranean seawater at $18^{\circ} \mathrm{C}$. Animals were fed every 3-4 d with Ulva lactuca that was gathered along the Mediterranean coast of Israel and kept frozen until needed. Animals were maintained on a 12-h light-dark cycle.

Animals were separated from each other one week before an experiment. They were thereafter kept in individual cages and were food-deprived. As in numerous previous studies examining learning that food is inedible in Aplysia (Botzer et al. 1998; Katzoff et al. 2002, 2006), $24 \mathrm{~h}$ before being trained they were transferred to $10-\mathrm{L}$ experimental aquaria that were maintained at room temperature $\left(23^{\circ} \mathrm{C}\right)$. They were kept two to an aquarium, with the two animals separated by a partition allowing the flow of water.

\section{Training}

Animals were trained and tested with inedible food, the seaweed Ulva wrapped in plastic net, as previously described (Schwarz et al. 1991; Botzer et al. 1998; Lyons et al. 2005; Levitan et al. 2008). Inedible food was touched to the lips, inducing biting and food entry into the mouth. Animals then attempted to swallow the food. The netted food cannot be swallowed and it became lodged in the buccal cavity, producing repetitive failed attempts to swallow. Food eventually left the buccal cavity. The experimenter continued to hold the food against the lips, inducing further biting responses, entries into the mouth, and failed swallows. As training proceeded many bites failed to cause entry of food into the mouth. When food did enter the mouth it stayed within for progressively shorter periods, eliciting fewer attempted swallows. In experiments testing memory, training continued until animals stopped responding for $3 \mathrm{~min}$ as evident by lack of food entering the mouth. In all animals, food was in the mouth eliciting failed attempts to swallow for at least 100 sec of the initial training, since previous experience showed that such animals almost always show long-term memory. Animals in which food was not in the mouth for 100 sec during training were discarded. Such a training session caused long-term memory measured after $24 \mathrm{~h}$ (Fig. 6). The total time the animal retained food in the mouth was used as a parameter of learning. Memory was measured by a decrease in this parameter in a test session that was identical to the procedure during the training. Tests of memory were performed using a blind procedure.

In experiments measuring mRNA synthesis after training, the training was identical to that described, except that the training was stopped after $15 \mathrm{~min}$, rather than allowing animals to stop responding to the food. This was done to create a standard time used for training and for lip stimulation in control animals. A 15-min training is a long enough training to create long-term memory (Botzer et al. 1998; Levitan et al. 2010). Animals were then sacrificed.

Some experiments examined the effects of lip stimulation without entry of food into the mouth. In these experiments the lips were stimulated with inedible netted food, which elicited bites. The food was not allowed to enter the mouth, and therefore no swallows were elicited. The lips were stimulated with food for $15 \mathrm{~min}$. Trained, lip-stimulated, and naive animals were handled identically

\section{Quantitative real-time PCR}

After treatments, animals were anesthetized with isotonic $\mathrm{MgCl}_{2}$ (25\%-50\% of the body weight), and the buccal ganglia were removed. The mechanoafferent neuron clusters were separated from the rest of the ganglia rapidly on a cold steel platform in cold ASW. The separation procedure took no more than 810 min. Total RNA was extracted using EZ-RNA (Biological Industries Israel Beit-Haemek Ltd.). DNA contamination was eliminated using DNA-free DNase (Ambion). Reverse transcription was applied using a high capacity archive kit (RevertAid H minus First Strand cDNA synthesis kit, Fermentase). Samples were analyzed in triplicate using an MJ opticon 2 detection system. Analysis of mRNA levels was done using comparative Ct method (Livak and Schmittgen 2001). Real time quantitative PCR was performed using SYBR-green kit (ABgene Ltd.) with the following primers: ApC/EBP, forward primer 5'-GCAACTCAGCAACGCAACAAATGC-3', reverse primer 5' -TTTAGCGGAGATGTGGCATGGAGT-3'; sensorin-A, forward primer 5'-TGATGGTCGTCCTTTGCATCGTGT-3', reverse primer 5'-TTCTTGACTCACCAACTGCCTGGA-3'; histone H4, forward primer 5'-GGTGGTGTGAAGCGTATTTCTGGT-3', reverse primer 5'-GGCCTTGACGTTTGAGAGCATAGA-3'.

As in previous experiments examining the expression of $A p C / E B P$ after training with inedible food (Levitan et al. 2008), data on the expression of $A p C / E B P$ or sensorin-A for each sample were normalized to the expression of histone $\mathrm{H} 4 \mathrm{mRNA}$ in the same sample. The value of $\mathrm{C}-\mathrm{EBP} / \mathrm{H} 4$ or of sensorin-A/H4 obtained for each sample, from both trained and naive animals, was further normalized and expressed as a percentage of the mean value of $\mathrm{C}-\mathrm{EBP} / \mathrm{H} 4$ or sensorin-A/H4 in naive animals in the same experiment, which was set at $100 \%$. Thus, each ganglion from a naive animal has a different value, but the mean of all these values was set at $100 \%$.

\section{Electrophysiology}

Animals were anesthetized with isotonic $\mathrm{MgCl}_{2}(25 \%-50 \%$ of the body weight). The buccal ganglia were then removed from the 
animals and placed in a chamber containing filtered ASW. The ganglia were then desheathed. Recordings were at room temperature with $1 \mathrm{M} \mathrm{KCl}$ electrodes (10-20 M $\Omega$ ), via an Axoclamp 2 voltage clamp/amplifier (Axon Instruments) used in current clamp mode. Data were acquired and analyzed using PC computers running the Clampex component of pClamp 8.0 software (Axon Instruments), with a sampling rate of $10 \mathrm{kHz}$. A/D and D/A conversions were performed by a Digidata 1322A digitizer (Axon Instruments).

\section{Statistics}

Because of the 10-fold increase in expression caused by training, for data on the effects of lip stimulation and training on the expression of $\mathrm{C} / \mathrm{EBP}$, there was a significant heterogeneity of variance for the sensory cells between the three groups both 15 min (Levene statistic $(2,13)=4.57 ; P=0.031$ ) and $2 \mathrm{~h}$ (Levene statistic $(2,25)=11.16 ; P<0.001)$ after training. For this reason, nonparametric statistics (Mann-Whitney $U$-tests, two tailed) were used to test changes in expression of C/EBP. Increases in sensorin-A were more modest, and there was no heterogeneity of variance between the three groups at either $15 \mathrm{~min}$ (Levene statistic $(2,11)=2.96$; $P=0.09)$ or at $2 \mathrm{~h}$ (Levene statistic $(2,22)=1.02 ; P=0.38$ ) after training. When testing for changes in expression in sensorin-A, or of other genes showing homogeneity of variance, parametric statistics were used.

\section{Acknowledgments}

The research was supported by Israel Science Foundation Grant No. 506/09. We thank Dr. Hillel Chiel for comments on the manuscript.

\section{References}

Alberini CM. 2009. Transcription factors in long-term memory and synaptic plasticity. Physiol Rev 89: 121-145.

Alberini CM, Ghirardi M, Metz R, Kandel ER. 1994. C/EBP is an immediate-early gene required for the consolidation of long-term facilitation in Aplysia. Cell 25: 1099-1114.

Baxter DA, Byrne JH. 2006. Feeding behavior of Aplysia: A model system for comparing cellular mechanisms of classical and operant conditioning. Learn Mem 13: 669-680.

Benjamin PR, Staras K, Kemenes G. 2000. A systems approach to the cellular analysis of associative learning in the pond snail Lymnaea. Learn Mem 7: $124-131$

Borovikov D, Evans CG, Jing J, Rosen SC, Cropper EC. 2000. A proprioceptive role for an exteroceptive mechanoafferent neuron in Aplysia. J Neurosci 20: 1990-2002.

Botzer D, Markovich S, Susswein AJ. 1998. Multiple memory processes following training that a food is inedible in Aplysia. Learn Mem 5: 204-219.

Brunet J-F, Shapiro E, Foster SA, Kandel ER, Yuichi I. 1991. Identification of a peptide specific for Aplysia sensory neurons by PCR-based differential screening. Science 252: 856-859.

Byrne JH, Kandel ER. 1996. Presynaptic facilitation revisited: State and time dependence. J Neurosci 16: 425-435.

Cai D, Chen S, Glanzman DL. 2008. Postsynaptic regulation of long-term facilitation in Aplysia. Curr Biol 18: 920-925.

Carew T, Castellucci VF, Kandel ER. 1979. Sensitization in Aplysia: Restoration of transmission in synapses inactivated by long-term habituation. Science 205: 417-419.

Castellucci VF, Carew TJ, Kandel ER. 1978. Cellular analysis of long-term habituation of the gill-withdrawal reflex of Aplysia californica. Science 202: $1306-1308$.

Chiel HJ, Susswein AJ. 1993. Learning that food is inedible in freely-behaving Aplysia californica. Behav Neurosci 107: 327-338.

Chiel HJ, Ting LH, Ekeberg O, Hartmann MJ. 2009. The brain in its body: Motor control and sensing in a biomechanical context. J Neurosci 29: 12807-12814.

Cleary LJ, Lee W, Byrne JH. 1998. Cellular correlates of long term sensitization in Aplysia. J Neurosci 18: 5988-5998.

Cohen-Armon M, Visochek L, Katzoff A, Levitan D, Susswein AJ, Klein R, Val-brun M, Schwartz JH. 2004. Long-term memory requires PolyADP-ribosylation. Science 304: 1820-1822.
Cropper EC, Evans CG, Hurwitz I, Jing J, Proekt A, Romero A, Rosen SC. 2004. Feeding neural networks in the mollusc Aplysia. Neurosignals 13: 70-86.

Dembrow NC, Jing J, Brezina V, Weiss KR. 2004. A specific synaptic pathway activates a conditional plateau potential underlying protraction phase in the Aplysia feeding central pattern generator. J Neurosci 24: 5230-5238.

Elliott CJ, Susswein AJ. 2002. Comparative neuroethology of feeding control in molluscs. J Exp Biol 20: 877-896.

Evans CG, Cropper EC. 1998. Proprioceptive input to feeding motor programs in Aplysia. J Neurosci 18: 8016-8031.

Evans CG, Alexeeva V, Rybak J, Karhunen T, Weiss KR, Cropper EC. 1999. A pair of reciprocally inhibitory histaminergic sensory neurons are activated within the same phase of ingestive motor programs in Aplysia. J Neurosci 19: 845-858.

Fiore L, Meunier J-M. 1979. Synaptic connections and functional organization in Aplysia buccal ganglia. J Neurobiol 10: 13-29.

Frankland PW, Josselyn SA, Anagnostaras SG, Kogan JH, Takahashi E, Silva AJ. 2004. Consolidation of CS and US representations in associative fear conditioning. Hippocampus 14: 557-569.

Glanzman DL. 2010. Common mechanisms of synaptic plasticity in vertebrates and invertebrates. Curr Biol 20: R31-R36.

Guan Z, Giustetto M, Lomvardas S, Kim JH, Miniaci MC, Schwartz JH, Thanos D, Kandel ER. 2002. Integration of long-term-memory-related synaptic plasticity involves bidirectional regulation of gene expression and chromatin structure. Cell 111: 483-493.

Gusev PA, Cui C, Alkon DL, Gubin AN. 2005. Topography of Arc/Arg3.1 mRNA expression in the dorsal and ventral hippocampus induced by recent and remote spatial memory recall: Dissociation of CA3 and CA1 activation. J Neurosci 25: 9384-9397.

Hatakeyama D, Sadamoto H, Watanabe T, Wagatsuma A, Kobayashi S, Fujito Y, Yamashita M, Sakakibara M, Kemenes G, Ito E. 2006. Requirement of new protein synthesis of a transcription factor for memory consolidation: Paradoxical changes in mRNA and protein levels of C/EBP. J Mol Biol 356: 569-577.

Hu JY, Glickman L, Wu F, Schacher S. 2004. Serotonin regulates the secretion and autocrine action of a neuropeptide to activate MAPK required for long-term facilitation in Aplysia. Neuron 43: 373-385.

$\mathrm{Hu}$ JY, Wu F, Schacher S. 2006. Two signaling pathways regulate the expression and secretion of a neuropeptide required for long-term facilitation in Aplysia. J Neurosci 26: 1026-1035.

Hu JY, Chen Y, Bougie JK, Sossin WS, Schacher S. 2010. Aplysia cell adhesion molecule and a novel protein kinase $\mathrm{C}$ activity in the postsynaptic neuron are required for presynaptic growth and initial formation of specific synapses. J Neurosci 30: 8353-8366.

Hurwitz I, Goldstein RS, Susswein AJ. 1994. Compartmentalization of pattern-initiation and motor functions in the B31 and B32 neurons of the buccal ganglia of Aplysia californica. J Neurophysiol 71: 1514-1527.

Hurwitz I, Neustadter D, Morton D, Chiel HJ, Susswein AJ. 1996. Activity patterns of the B31/B32 pattern initiators innervating the I2 muscle of the buccal mass during normal feeding movements in Aplysia californica. J Neurophysiol 75: 1309-1326.

Hurwitz I, Kupfermann I, Susswein AJ. 1997. Different roles of neurons B63 and B34 that are active during the protraction phase of buccal motor programs in Aplysia californica. J Neurophysiol 78: 1305-1319.

Hurwitz I, Cropper EC, Vilim FS, Alexeeva V, Susswein AJ, Kupfermann I, Weiss KR. 2000. Serotonergic and peptidergic modulation of the buccal mass protractor muscle (I2) in Aplysia. J Neurophysiol 84: 2810-2820.

Hurwitz I, Ophir A, Korngreen A, Koester J, Susswein AJ. 2008. Currents contributing to decision-making in neurons B31/B32 of Aplysia. J Neurophysiol 99: 814-830.

Jing J, Weiss KR. 2001. Neural mechanisms of motor program switching in Aplysia. J Neurosci 21: 7349-7362.

Jing J, Weiss KR. 2002. Interneuronal basis of the generation of related but distinct motor programs in Aplysia: Implications for current neuronal models of vertebrate intralimb coordination. J Neurosci 22: $6228-6238$.

Kandel ER. 2001. The molecular biology of memory storage: A dialogue between genes and synapses. Science 294: 1030-1038.

Katzoff A, Ben-Gedalya T, Susswein AJ. 2002. Nitric oxide is necessary for multiple memory processes after learning that a food is inedible in Aplysia. J Neurosci 22: 9581-9594.

Katzoff A, Ben-Gedalya T, Hurwitz I, Miller N, Susswein YZ, Susswein AJ. 2006. Nitric oxide signals that Aplysia have attempted to eat, a necessary component of memory formation after learning that food is inedible. J Neurophysiol 96: 1247-1257.

Katzoff A, Miller N, Susswein AJ. 2010. Nitric oxide and histamine signal attempts to swallow: A component of learning that food is inedible in Aplysia. Learn Mem 17: 50-62. 
Kubik S, Miyashita T, Guzowski JF. 2007. Using immediate-early genes to map hippocampal subregional functions. Learn Mem 14: 758-770.

Kuhl D, Kennedy TE, Barzilai A, Kandel ER. 1992. Long-term sensitization training in Aplysia leads to an increase in the expression of $\mathrm{BiP}$, the major protein chaperon of the ER. J Cell Biol 119: 1069-1076.

Levitan D, Lyons LC, Perelman A, Green CL, Motro B, Eskin A, Susswein AJ. 2008. Training with inedible food in Aplysia causes expression of C/EBP in the buccal but not cerebral ganglion. Learn Mem 15: 412-416.

Levitan D, Twitto R, Levy R, Lyons LC, Susswein AJ. 2010. A brief retraining regulates the persistence and lability of a long-term memory. Learn Mem 17: $402-406$.

Liu QR, Hattar S, Endo S, MacPhee K, Zhang H, Cleary LJ, Byrne JH, Eskin A. 1997. A developmental gene (Tolloid/BMP-1) is regulated in Aplysia neurons by treatments that induce long-term sensitization. J Neurosci 17: $755-764$.

Livak KJ, Schmittgen TD. 2001. Analysis of relative gene expression data using real-time quantitative PCR and the $2_{\mathrm{T}}^{-\Delta \Delta C}$ method. Methods 25: $402-408$.

Lyons LC, Rawashdeh O, Katzoff A, Susswein AJ, Eskin A. 2005. Circadian modulation of complex learning in diurnal and nocturnal Aplysia. Proc Natl Acad Sci 102: 12589-12594.

Lyons LC, Collado MS, Khabour O, Green CL, Eskin A. 2006. The circadian clock modulates core steps in long-term memory formation in Aplysia.J Neurosci 26: 8662-8671.

Mamiya N, Fukushima H, Suzuki A, Matsuyama Z, Homma S, Frankland PW, Kida S. 2009. Brain region-specific gene expression activation required for reconsolidation and extinction of contextual fear memory. J Neurosci 29: 402-413.

Maviel T, Durkin TP, Menzaghi F, Bontempi B. 2004. Sites of neocortical reorganization critical for remote spatial memory. Science 305: 96-99.

Michel M, Green CL, Lyons LC. 2010. PKA and PKC are required for long-term but not short-term in vivo operant memory in Aplysia. Learn Mem 18: $19-23$.

Michel M, Green CL, Eskin A, Lyons LC. 2011. PKG-mediated MAPK signaling is necessary for long-term operant memory in Aplysia. Learn Mem 18: 108-117.

Michel M, Green CL, Gardner JS, Ogan CL, Lyons LC. 2012. Massed training-induced intermediate-term operant memory in Aplysia requires protein synthesis and multiple persistent kinase cascades. J Neurosci 32: 4581-4591.

Milekic MH, Pollonini G, Alberini CM. 2007. Temporal requirement of C/ EBP $\beta$ in the amygdala following reactivation but not acquisition of inhibitory avoidance. Learn Mem 14: 504-511.

Miller MW, Rosen SC, Schissel SL, Cropper EC, Kupfermann I, Weiss KR. 1994. A population of SCP-containing neurons in the buccal ganglion of Aplysia are radula mechanoafferents and receive excitation of central origin. J Neurosci 14: 7008-7023.

Miller N, Saada R, Fishman S, Hurwitz I, Susswein AJ. 2011. Neurons controlling Aplysia feeding inhibit themselves by continuous NO production. PLoS One 6: e17779. doi: 10.1371/ journal.pone.0017779.

Nargeot R, Baxter DA, Byrne JH. 1999. In vitro analog of operant conditioning in Aplysia. II. Modifications of the functional dynamics of an identified neuron contribute to motor pattern selection. J Neurosci 19: $2261-2272$.

Nargeot R, Le Bon-Jego M, Simmers J. 2009. Cellular and network mechanisms of operant learning-induced compulsive behavior in Aplysia. Curr Biol 19: 975-984.

Neustadter DM, Herman RL, Drushel RF, Chestek DW, Chiel HJ. 2007. The kinematics of multifunctionality: Comparisons of biting and swallowing in Aplysia californica. J Exp Biol 210: 238-260.
Nikitin ES, Vavoulis DV, Kemenes I, Marra V, Pirger Z, Michel M, Feng J, O'Shea M, Benjamin PR, Kemenes G. 2008. Persistent sodium current is a nonsynaptic substrate for long-term associative memory. Curr Biol 18: $1221-1226$.

Reissner KJ, Shobe JL, Carew TJ. 2006. Molecular nodes in memory processing: Insights from Aplysia. Cell Mol Life Sci 63: 963-974.

Roberts AC, Glanzman DL. 2003. Learning in Aplysia: Looking at synaptic plasticity from both sides. Trends Neurosci 26: 662-670.

Saada R, Miller N, Hurwitz I, Susswein AJ. 2009. Autaptic excitation elicits persistent activity and a plateau potential in a neuron of known behavioral function. Curr Biol 19: 479-484.

Schwarz M, Markovich S, Susswein AJ. 1988. Parametric features of inhibition of feeding in Aplysia by associative learning, satiation, and sustained lip stimulation. Behav Neurosci 102: 124-133.

Schwarz M, Feldman E, Susswein AJ. 1991. Variables affecting long-term memory of learning that a food is inedible in Aplysia. Behav Neurosci 105: $193-201$.

Sharma SK, Carew TJ. 2004. The roles of MAPK cascades in synaptic plasticity and memory in Aplysia: Facilitatory effects and inhibitory constraints. Learn Mem 11: 373-378.

Sun ZY, Wu F, Schacher S. 2001. Rapid bidirectional modulation of mRNA expression and export accompany long-term facilitation and depression of Aplysia synapses. J Neurobiol 46: 41-47.

Susswein AJ, Schwarz M, Feldman E. 1986. Learned changes of feeding behavior in Aplysia in response to edible and inedible foods. J Neurosci 6: $1513-1527$.

Susswein AJ, Byrne JH. 1988. Identification and characterization of neurons initiating patterned neural activity in the buccal ganglia of Aplysia. J Neurosci 8: 2049-2061.

Susswein AJ, Hurwitz I, Thorne R, Byrne JH, Baxter DA. 2002. Mechanisms underlying fictive feeding in Aplysia: Coupling between a large neuron with plateau potentials activity and a spiking neuron. J Neurophysiol 87: 2307-2323.

Taubenfeld SM, Milekic MH, Monti B, Alberini CM. 2001a. The consolidation of new but not reactivated memory requires hippocampal C/EBPß. Nat Neurosci 4: 813-818.

Taubenfeld SM, Wiig KA, Monti B, Dolan B, Pollonini G, Alberini CM. 2001b. Fornix-dependent induction of hippocampal CCAAT enhancer-binding protein $\beta$ and $\Delta$ co-localizes with phosphorylated cAMP response element-binding protein and accompanies long-term memory consolidation. J Neurosci 21: 84-91.

Vilim FS, Sasaki K, Rybak J, Alexeeva V, Cropper EC, Jing J, Orekhova IV, Brezina V, Price D, Romanova EV, et al. 2010. Distinct mechanisms produce functionally complementary actions of neuropeptides that are structurally related but derived from different precursors. J Neurosci 30: 131-147.

Walters ET, Bodnarova M, Billy AJ, Dulin MF, Diaz-Rios M, Miller MW, Moroz LL. 2004. Somatotopic organization and functional properties of mechanosensory neurons expressing sensorin-A mRNA in Aplysia californica. J Comp Neurol 471: 219-240.

Wang DO, Kim SM, Zhao Y, Hwang H, Miura SK, Sossin WS, Martin KC. 2009. Synapse- and stimulus-specific local translation during long-term neuronal plasticity. Science 324: 1536-1540.

Warman EN, Chiel HJ. 1995. A new technique for chronic single extracellular recording in freely behaving animals using pipette electrodes. J Neurosci Meth 57: 161-169.

Ye H, Morton DW, Chiel HJ. 2006. Neuromechanics of multifunctionality during rejection in Aplysia californica. J Neurosci 18: 10743-10755.

Received March 13, 2012; accepted in revised form July 12, 2012. 


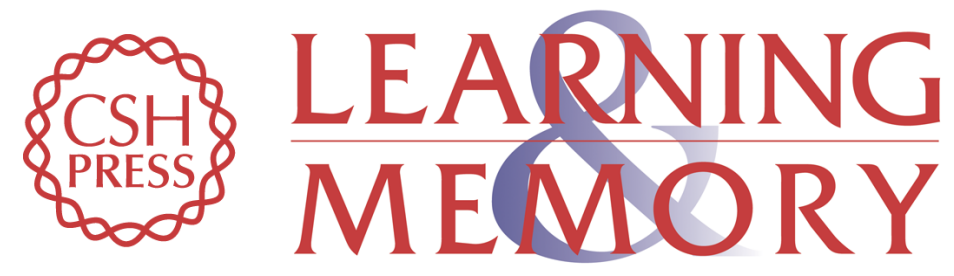

Localization of molecular correlates of memory consolidation to buccal ganglia mechanoafferent neurons after learning that food is inedible in Aplysia

David Levitan, Ravit Saada-Madar, Anastasiya Teplinsky, et al.

Learn. Mem. 2012, 19:

Access the most recent version at doi:10.1101//m.026393.112

Supplemental Material

References License

Email Alerting Service
http://learnmem.cshlp.org/content/suppl/2012/10/04/19.11.503.DC1

This article cites 77 articles, 44 of which can be accessed free at: http://learnmem.cshlp.org/content/19/11/503.full.html\#ref-list-1

Receive free email alerts when new articles cite this article - sign up in the box at the top right corner of the article or click here. 